\title{
Tribenuron Metil'in Zebra Balığı Embriyo ve Larvaları Üzerine Teratolojik Etkileri
}

\author{
Nazan Deniz YÖN ERTUĞ' ${ }^{1}$, Tarı DİNÇ²*, Burcu ÖZTÜRK ${ }^{3}$ \\ *Sorumlu yazar: tdinc@sakarya.edu.tr \\ ${ }^{1}$ Sakarya Üniversitesi, Fen Edebiyat Fakültesi, Biyoloji Bölümü, SAKARYA \\ Orcid No: 0000-0002-6830-8971 / ndyon@sakarya.edu.tr \\ ${ }^{2 *}$ Sakarya Üniversitesi, Fen Edebiyat Fakültesi, Biyoloji Bölümü, SAKARYA \\ Orcid No: 0000-0003-3481-0872 / tdinc@sakarya.edu.tr \\ ${ }^{3}$ Sakarya Üniversitesi, Fen Edebiyat Fakültesi, Biyoloji Bölümü, SAKARYA \\ Orcid No: 0000-0002-2506-8904 / bozturk911@gmail.com
}

\begin{abstract}
Öz: Tribenuron metil tarımda çok yıllık dikotları kontrol etmek için kullanılan herbisittir. Sucul ekosistemlere yeraltı suyu yoluyla erişebilir ve sucul yaşamı etkileyebilir. Zebra balığı (Danio rerio Hamilton, 1822), kolay üreme kapasitesine ve şeffaf embriyolara sahip olan ve bu yüzden bilimsel çalışmalarda sıkça tercih edilen bir omurgalı modelidir. Bu çalışmada tribenuron metil zebra balıkları üzerinde 120 saatlik $\mathrm{LC}_{50}$ değerinin $1.850 \mathrm{mg} \mathrm{L}^{-1}$ olarak tespit edildi. Bu değerden yola çıkarak uygulanan $1.812 \mathrm{mg} \mathrm{L}^{-1}, 0.906 \mathrm{mg} \mathrm{L}^{-1}, 0.453 \mathrm{mg} \mathrm{L}^{-1}$, $0.226 \mathrm{mg} \mathrm{L}^{-1}$ ve $0.113 \mathrm{mg} \mathrm{L}^{-1}$ konsantrasyonlarında tribenuron metilin zebra balığı embriyo ve larva gelişimine olan etkisi incelenmiştir. Bu çalışma sonucunda tribenuron metil uygulamasının embriyo hücrelerinde toksik etki ettiği, farklı malformasyonlara sebep olduğu tespit edilmiştir.
\end{abstract}

Anahtar Kelimeler: Tribenuron Metil, Zebra Balığı (Danio rerio), Embriyo Toksite Testi, Teratoloji

\section{Teratological Effects of Tribenuron Methyl on Zebra Fish Embryo and Larva}

\begin{abstract}
Tribenuron methyl is an herbicide used in agriculture to control perennial dicots. It can access aquatic ecosystems through groundwater and affect aquatic life. The zebrafish (Danio rerio Hamilton, 1822 ) is a vertebrate model that has an easy reproductive capacity and transparent embryos therefore frequently preferred in scientific studies. In this study, the effects of $1.812 \mathrm{mg} \mathrm{L}^{-1}, 0.906 \mathrm{mg} \mathrm{L}^{-1}, 0.453 \mathrm{mg} \mathrm{L}^{-1}, 0.226 \mathrm{mg} \mathrm{L}^{-1}$ and $0.1113 \mathrm{mg} \mathrm{L}^{-1}$ tribenuron methyl on zebrafish embryo and larval development were investigated. As a result of this study, it was determined that tribenuron methyl administration had toxic effects on embryo cells and caused different malformations.
\end{abstract}

Keywords: Tribenuron Methyl, Zebrafish (Danio rerio), Embryo Toxicity Test, Teratology

\section{Giriş}

Pestisitler

tarımda

zararl1

organizmaları engellemek veya kontrol altına almak için kullanılan madde ya da madde karışımlarıdır. Engellenmek istenen canlıya göre farklı pestisit türleri bulunmaktadır. Farklı canlı türlerini hedef alarak kullanılan bu ilaçlar, farklı yollarla doğaya salınmaktadır. Suda, toprakta bozunmadan kalan pestisitler, çevre kirliliğine sebep olmakta ve besin zinciri yolu ile canlıları olumsuz yönde etkilemektedir (Vural, 1984; Toros ve Maden, 1985).

Tribenuron metil, tarımda yabanc1 otlara karşı üretilen bazı tarım ilaçlarının ana 
etken maddesi olarak farklı konsantrasyonlarda kullanılan bir pestisit çeşididir. Tribenuron metil; kökler ve yeşil aksam yoluyla yabanc1 otlar tarafindan bünyelerine alınır. Topraktaki kalıcı etkisi azdir. Tribenuron metil, düşük konsantrasyonlarda bile büyük fitotoksik etkiye sahip olan sulfonil üre grubu herbisitir. Tribenuron metil tarımda birçok ilacın etkin maddesi olarak kullanılmaktadır (EPA, 2009). Diğer sulfonil üre bileşikleri ile karşılaştırıldığında, tribenuron metil'in belirlenmesi ile ilgili çok az çalışma yapılmıştır.

Şeffaf embriyo özelliğine sahip olan; Zebra balığı (Danio rerio Hamilton, 1822) 1930'lardan beri yaygın olarak üzerine çalışılan model bir organizmadır. Zebra balığı, birçok ilaç veya hastalık tedavi ve tespit çalışmalarında tercih edilen bir model organizmadır. Bu balık türünün embriyonik gelişimi, gelişimi sırasındaki morfolojik ve biyokimyasal süreçleri hakkında çok şey bilinmektedir (Kimmel ve ark., 1995). Son yıllarda zararlı kimyasal maddelerin gelişim aşamasında verdiği hasarların değerlendirilmesinde, zebra balığ embriyoları döllenmeden kısa bir süre sonra koryondan çıkması ve gelişiminin hızlı olması nedeni ile toksik madde riskini değerlendirmede bir model organizma olarak kullanılmaktadır. Balığın embriyo döneminde dış madde veya zarara karşı kendisini korunmasına rağmen yapısal ve işlevsel değişikliklerin ne olacağı merak konusu olmuştur (Glaberman, 2017).

Tribenuron metilin endokrin bozucu potansiyeli olduğundan embriyoları yakından etkilemektedir. Dolayısıyla çalışma boyunca zebra balığı embriyolarında düşük dozlarda tribenuron metil uygulanarak, bu maddenin balığın dişarıya en hassas olduğu dönem olan embriyo ve larval döneminde etkileri incelenmiştir.

\section{Materyal ve Metot}

\subsection{Tribenuron Metil}

Tribenuron metil, Dupont firmasından temin edilmiştir. 101200-48-0 CAS numaralı olup tarım ilacı olarak herbisit amaçlı üretilmiştir. Ticari ismi "Granstar" (WG, \%75 tribenuronmethyl)'dir.

\subsection{Zebra Balığı Yetiştirilmesi ve}

\section{Yumurtalarının Toplanması}

Sakarya Üniversitesi Fen Edebiyat Fakültesi Biyoloji Bölümü Araştırma Laboratuvarı içerisine zebra balığı ile yapılacak deneyler için akvaryum sistemi kuruldu. Akvaryumların içerisine dinlendirilmiş musluk suyu konulup sıcaklık termostatlı bir 1 sitıcı ile $28^{\circ} \mathrm{C}$ olacak şekilde ayarlandi. Akvaryum içerisindeki sular hava motorları ile oksijenlendirildi. Oda içerisine 14 saat aydınlık 10 saat karanlık olacak şekilde aydınlatma sistemi kurularak balıkların gelişim süreci için gerekli olan fotoperiyot oluşturuldu. Yumurta toplamak 
için, zebra balıkları 2 dişiye 5 erkek gelecek şekilde $24 \times 28 \times 40 \mathrm{~cm}$ ebadında çiftleştirme akvaryumlarına yerleştirildi. Döllenmiş yumurtalar ve gelişim evresinde olan embriyolar stereo mikroskop altında incelendi. Normal gelişim gösteren embriyolar denemelere başlayıncaya kadar $28{ }^{\circ} \mathrm{C}$ 'lik etüv içerisinde bekletildi.

2.3. Embriyo ve Larval Toksisite Testi

$\mathrm{Bu}$ araştırmada, tribenuron metilin toksisitesini belirlemek amaciyla, teratojenite testi (USEPA) kullanıldı (Glaberman, 2017). $\mathrm{Bu}$ teste göre, toksisitesinden şüphelenilen kimyasal maddenin LC50 değerini belirlemek için, kontrol ve deney gruplarında her petride 20 zebra balı̆̆ 1 embriyosu olacak şekilde düzenlendi. Deney gruplarındaki zebra balığ embriyolarına blastula evresinde $1 \mathrm{~g}$ $\mathrm{L}^{-1}, 100 \mathrm{mg} \mathrm{L}^{-1}, 10 \mathrm{mg} \mathrm{L}^{-1}, 1 \mathrm{mg} \mathrm{L}^{-1}, 0.1 \mathrm{mg}$

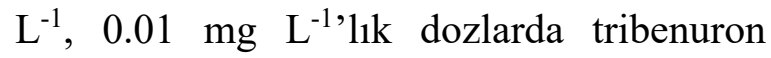
metil uygulaması yapıldı ve embriyoların gelişimleri 120 saat süre zarfında gözlendi. Probit yöntemi (Tyler ve Gurian, 1950) ile $\mathrm{LC}_{50} \quad 1.850 \mathrm{mg} \quad \mathrm{L}^{-1}$ olarak hesapland. Uygulama konsantrasyonları olarak 1.812 $\mathrm{mg} \mathrm{L}{ }^{1}, 0.906 \mathrm{mg} \mathrm{L}^{-1}, 0.453 \mathrm{mg} \mathrm{L}^{-1}, 0.226$ $\mathrm{mg} \mathrm{L} \mathrm{L}^{-1}, 0.113 \mathrm{mg} \mathrm{L} \mathrm{L}^{-1}, 0.056 \mathrm{mg} \mathrm{L}^{-1}$ olarak belirlenip; 120 saatlik uygulama sonucunda çeşitli anormallikler not edildi.

\subsection{Embriyo ve Larvalara}

\section{Tribenuron Metilin Uygulanması}

Tribenuron metilin uygulamas1 zigotlara ilk 0-2 saatlik zaman diliminde uyguland1. Kontrol grubunda sadece su kullanılırken, deney gruplarına $\mathrm{LC}_{50}$ değeri

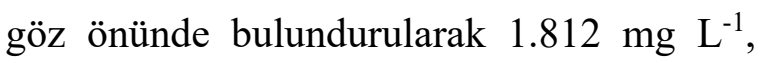
$0.906 \mathrm{mg} \mathrm{L}^{-1}, 0.453 \mathrm{mg} \mathrm{L}^{-1}, 0.226 \mathrm{mg} \mathrm{L}^{-1}$, $0.113 \mathrm{mg} \quad \mathrm{L}^{-1}, \quad 0.056 \quad \mathrm{mg} \quad \mathrm{L}^{-1}$ 'lik konsantrasyonlarda tribenuron metil uygulaması yapıld1. Kontrol ve deney gruplarında 20'şer adet embriyolar, $20 \mathrm{ml}$ solüsyonun içerisinde tutuldu. Embriyolar, 14 saat aydınlık:10 saat karanlık fotoperiyot uygulanan bir ortamda $28{ }^{\circ} \mathrm{C}$ 'ye ayarlı inkübatörde yaşatıldı. Gözlemler 24, 48, 72, 96 ve 120 saat aralıklarla yapıldı. Deney gruplarında meydana gelen anomaliler not edilip dijital kamera destekli 1 şık mikroskobuyla gözlenip fotoğrafları çekildi. Tribenuron metilin zebra balığ1 embriyolarında koryondan çıkma, ölüm ve anomali oranları üzerindeki etkileri tespit edildi.

\section{5. İstatistiksel Analiz}

IBM SPSS 23 programı kullanılarak, kontrol grupları ile uygulama doz grupları arasındaki istatistiksel olarak anlamlı fark olup olmadığını belirlemek için ANOVA testi kullanılmıştır. Doz grupları arasındaki farklar için TUKEY HSD testi kullanılmıştır. $\quad \mathrm{p}<0.05$ istatiksel olarak anlamlı fark kabul edilmiştir. 


\section{Araştırma Sonuçları}

\subsection{Zebra Balığında Gelişim} Evreleri

\subsubsection{Kontrol grubu}

Deney grubu dört kere tekrarlanmak üzere; toplam 80 adet embriyo incelendi. Döllenmiş yumurtaların gelişiminin 1 . gününde somit oluşumunun tamamlandığg, baş ve kuyruk bölgelerinin oluşması mikroskop altında şeffaf göründü (Şekil 1). 48 saatlik embriyolar normal gelişim gösterdi (Şekil 2).

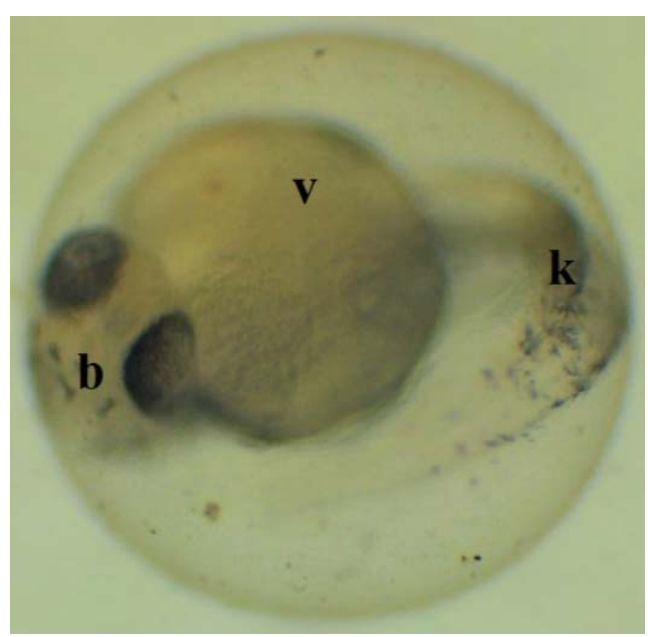

Şekil 1. Zebra balığı embriyosu 24 saatlik; b: baş bölgesi, k: kuyruk, v: vitellüs

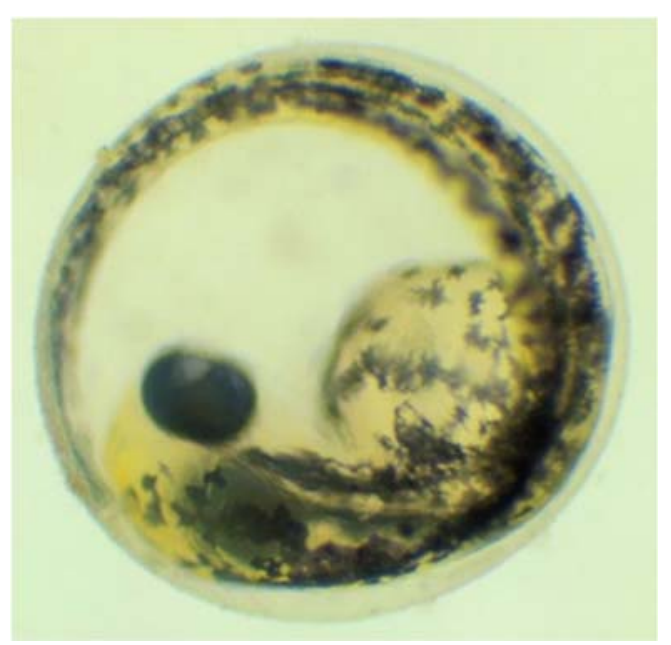

Şekil 2. 2 günlük zebra balığı embriyosu
Gelişimin 3. gününde Zebra balığ1 embriyolarının koryondan çıktığı gözlendi (Şekil 3). 4.gününden 7. gününe kadar zebra balığı petri kabında incelendi (Şekil 4).

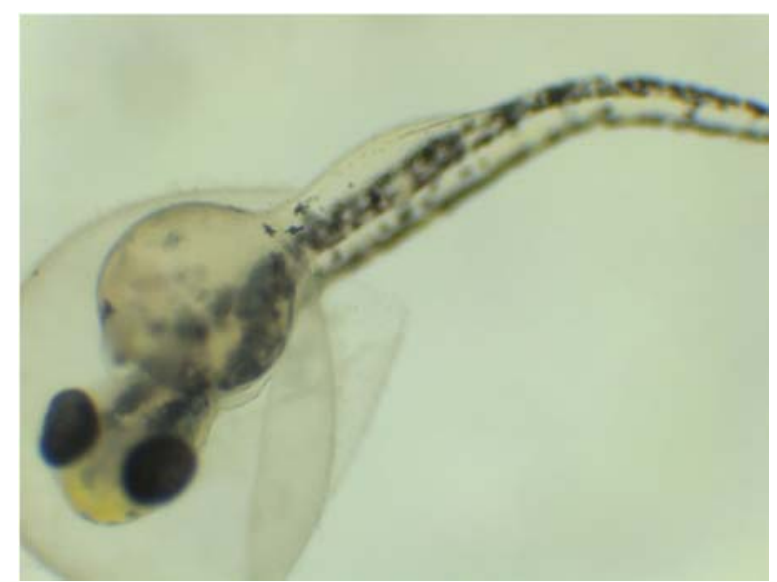

Şekil 3. 3 günlük zebra balığı embriyosunun koryondan çıkışı

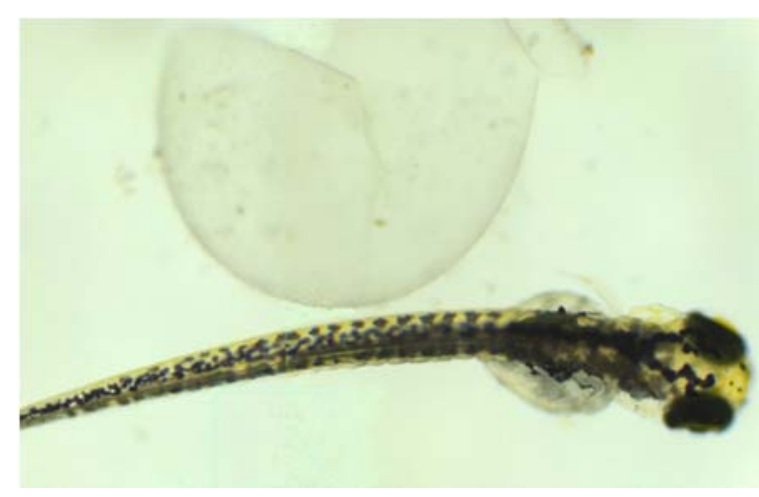

Şekil 4. 4 günlük zebra balığ

Zebra balığg larvaları 7. güne kadar vitellus kesesinden beslenirken, 7. gün itibari ile larvalar ağız yolu ile beslenmeye başladı.

\subsection{2. $0.056 \mathrm{mg} \mathrm{L}^{-1}$ Tribenuron}

\section{metil uygulaması yapılmış grup}

Deney grubu dört kere tekrarlanmak üzere; $0.056 \mathrm{mg} \mathrm{L}^{-1}$ tribenuron metil uygulaması yapılmış zebra balığ embriyoları kontrol grupları ile karşılaştırıldığında toplam 80 embriyo 
içerisinden biri 1. gün öldü. Kalan 79 embriyodan 4 embriyoda anomali gözlendi.

Gelişimin 1. gününde gelişim geriliği (Şekil 5a), 2. gününde pigmentasyon oluşumunda gecikmeler görüldü (Şekil 5b). 3. gününde ise koryondan çıkışlarda gecikmeler olduğu gözlendi (Şekil 5c). Zebra balığı embriyolarından bazıları koryondan çıkışını 4. gün gerçekleşti (Şekil 5d). Ayrıca anomali görülen balıklarda kalp atışı ilk üç günde ortalama dakikada $98 \mathrm{kez}$ olarak hesapland1.

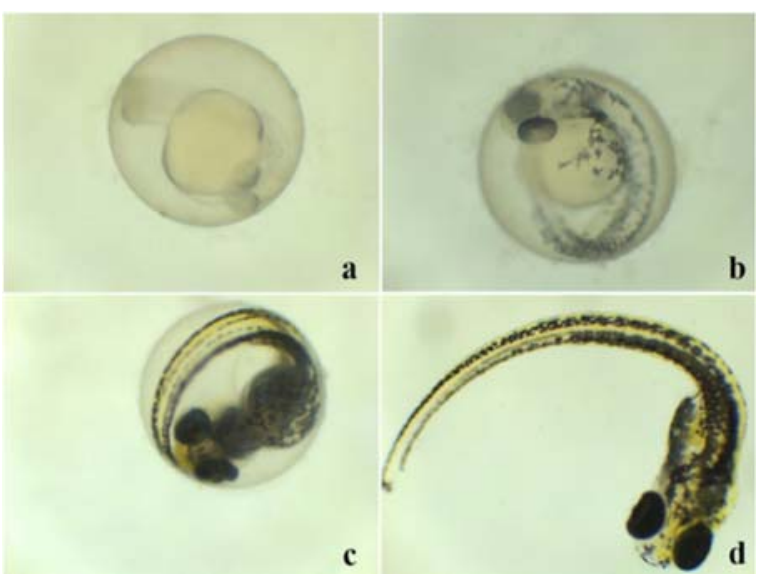

Şekil 5. $0.056 \mathrm{mg} \mathrm{L}^{-1}$ Tribenuron metil uygulaması yapılmış embriyo ve larvaları a) Gelişim geriliği, b) Yetersiz pigment oluşumu, c) Zebra balığ prelarvası 3. gün koryondan çıkışında gecikme, d) Zebra balığı prelarvası 4. gün koryondan çıkış.

\subsection{3. $0.113 \quad \mathrm{mg}^{-1} \quad \mathrm{~L}^{-1}$ Tribenuron} metil uygulaması yapılmış grup

Deney grubu dört kere tekrarlanmak üzere; $0.113 \mathrm{mg} \mathrm{L}^{-1}$ Tribenuron metil uygulaması yapılmış zebra balığ embriyoları kontrol grupları ile karşılaştırıldığında toplam 80 embriyo içerisinden üçü 1. gün öldü. Kalan 77 embriyodan 7 embriyoda anomali gözlendi. Gelişimin 1. gününde gelişim geriliği ve perikardiyal ödem (Şekil 6a), 2. gününde pigmentasyon oluşumunda gecikmeler ve perikardiyal ödemin büyümesi görüldü (Şekil 6b). 3. gününde koryondan çıkışta gecikmeler olduğu ve perikardiyal ödemlerin 2. güne kıyasla daha büyüdüğü izlendi (Şekil 6c ve Şekil 7). 4. gününde hala koryondan çıkmayan embriyolar tespit edildi (Şekil 6d). Bazı zebra balıkları koryondan çıkışını 5. gün gerçekleşti (Şekil 8). Ayrıca anomali görülen balıklarda ilk 3 günde kalp atışı ortalama dakikada $96 \mathrm{kez}$ olarak hesaplandi.

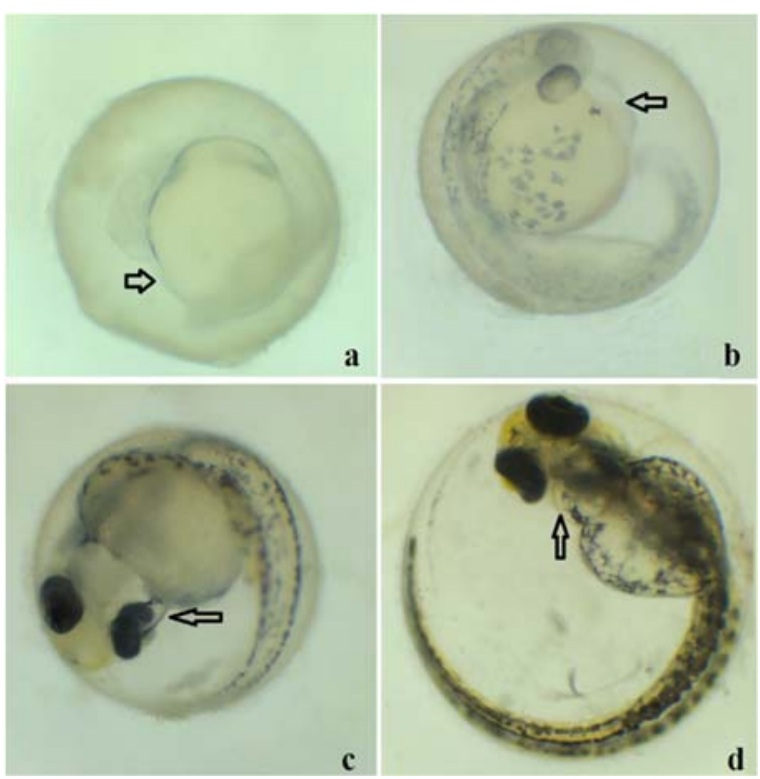

Şekil 6. $0.113 \mathrm{mg} \mathrm{L}^{-1}$ Tribenuron Metil uygulaması yapılmış embriyo ve larvaları, a) 1.gün zebra balığı prelarvası gelişim geriliği, ödem oluşumu (ok), b) 2.gün zebra balığı prelarvası yetersiz pigment oluşumu ve perikardiyal ödem (ok), c) 3.gün zebra balığı prelarvası koryondan çıkışında gecikme ve perikardiyal ödemde büyüme (ok), d) 4.gün zebra balığı prelarvası ve perikardiyal ödem (ok). 


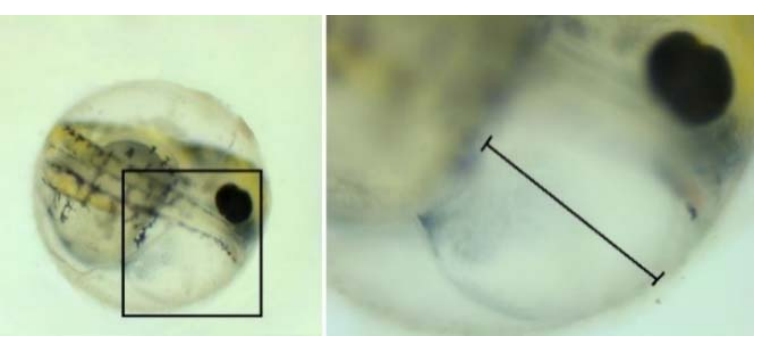

Şekil 7. $0.113 \mathrm{mg} \mathrm{L}^{-1}$ Tribenuron metil uygulaması yapılmış 4. gün zebra balığı prelarvası perikardiyal ödemin genişliği (çizgi)

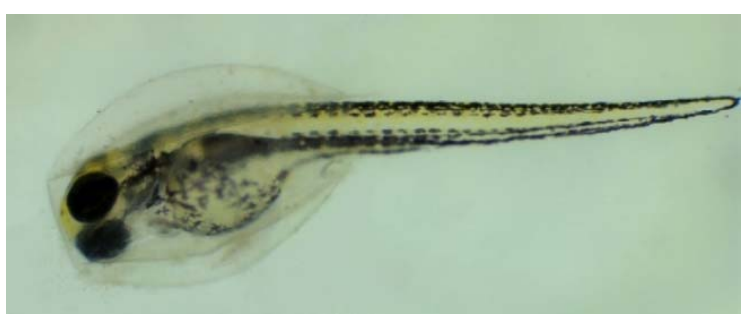

Şekil 8. $0.113 \mathrm{mg} \mathrm{L}^{-1}$ Tribenuron metil uygulaması yapılmış 5. gün zebra balığı prelarvası koryondan çıkış1

\subsection{4. $0.226 \mathrm{mg}^{-1} \quad \mathrm{~L}^{-1}$ Tribenuron}

\section{metil uygulaması yapılmış grup}

Deney grubu dört kere tekrarlanmak üzere; $0.226 \mathrm{mg} \mathrm{L}^{-1}$ Tribenuron metil uygulaması yapılmış zebra balı̆̆ embriyoları kontrol grupları ile karşılaştırıldığında toplam 80 embriyo içerisinden 7 tanesi 1. gün öldü. Kalan 73 embriyodan 14 embriyoda anomali gözlendi. Gelişimin 1. gününde belirgin olarak baş oluşmaması gibi gelişim geriliği (Şekil 9a), 2. gününde pigmentasyon oluşumunda gecikmeler ve perikardiyal ödemin büyümesi görüldü (Şekil 9b) 3. gününde koryondan çıkışlarında gecikmeler olduğu, pigmentasyon oluşumunun yavaşlı̆ğ ve perikardiyal ödem gözlendi (Şekil 9c). 5. gününde koryondan çıkışı tespit edildi. Ancak koryondan çıkan balıkların bazılarının kuyruğunda eğrilik ve perikardiyal ödemler gözlendi (Şekil 9d). Bununla birlikte bazı balıkların vitellüs kesesinde kısmen ödem, omurgada eğrilik ve perikardiyal ödem gözlendi (Şekil 10). Ayrıca anomali görülen balıklarda ilk 3 günde kalp atışı ortalama dakikada $94 \mathrm{kez}$ olarak hesapland1.

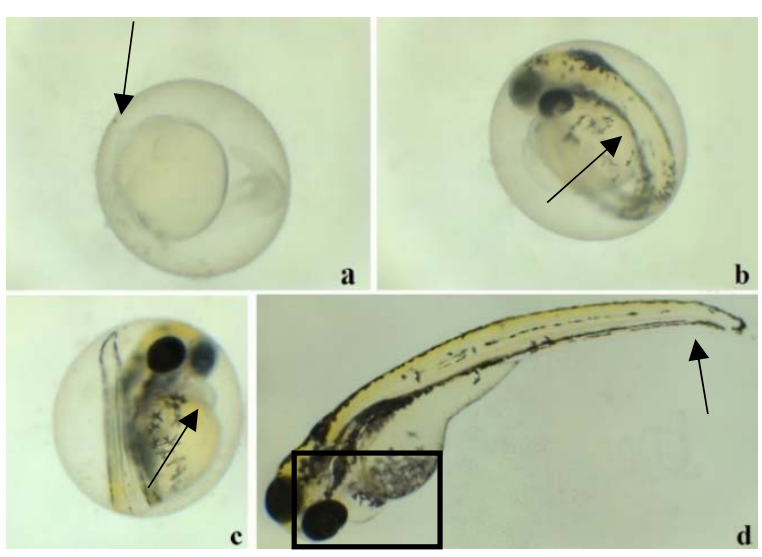

Şekil 9. $0.226 \mathrm{mg} \mathrm{L}^{-1}$ Tribenuron metil uygulaması yapılmış embriyo ve larvaları, a) 1. gün zebra balığ1 prelarvası gelişim geriliği, baş oluşumunun belirgin olmaması (ok), b) 2. gün zebra balığı prelarvası yetersiz pigment oluşumu ve perikardiyal ödem (ok), c) 3. gün zebra balığı prelarvası koryondan çıkışında gecikme ve perikardiyal ödemde büyüme (ok), d) 5 . gün zebra balığı embriyosunda perikardiyal ödem (kare), kuyruğunda eğrilik (ok).

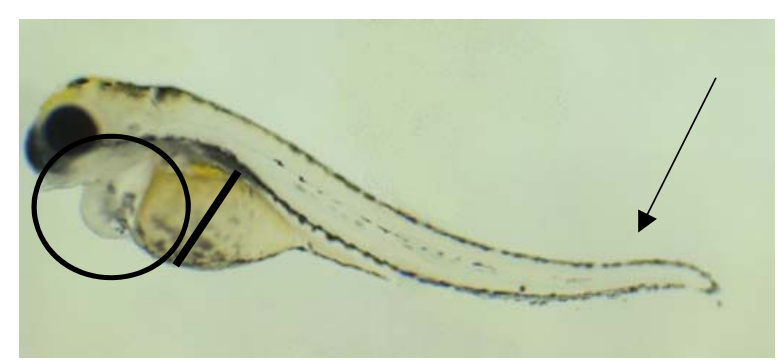

Şekil 10. $0.226 \mathrm{mg} \mathrm{L}^{-1}$ Tribenuron metil uygulaması yapılmış 5.gün zebra balığı embriyosunda perikardiyal ödem (daire), vitellüs kesesinde kısmen ödem (şişlik mesafesi çizgi), omurgada eğrilik (ok)

\subsection{5. $0.453 \mathrm{mg}^{-1}$ Tribenuron}

\section{metil uygulaması yapılmış grup}

Deney grubu dört kere tekrarlanmak üzere; $0.453 \mathrm{mg} \mathrm{L}^{-1}$ tribenuron metil uygulaması yapılmış zebra balı̆̆ embriyoları kontrol grupları ile 
karşılaştırıldığında toplam 80 embriyo içerisinde 13'ü 1. gün öldü. Kalan 67 embriyodan 27 embriyoda anomali gözlendi. Gelişimin 1. gününde belirgin olarak gelişim geriliği ve vitellüs kesesinde ödem (Şekil 11a), 3. gününde koryondan çıkışında gecikmeler, pigmentasyon oluşumunda gecikmeler ve kısmen perikardiyal ödemle birlikte içerisinde kanlanma görüldü (Şekil 11b). Bazı embriyolarda 5. gününde koryondan çıkış, perikardiyal ödem, vitellüs kesesinde ödem ve kuyrukta eğrilik gözlendi (Şekil 11c). Ayrıca 5. gününde koryondan çıkan bazı balıkların omurgasında eğrilik belirlendi (Şekil 11d). Bu anomalilere ilaveten ilk 3 günde kalp atışı ortalama dakikada 87 kez olarak hesaplandı.

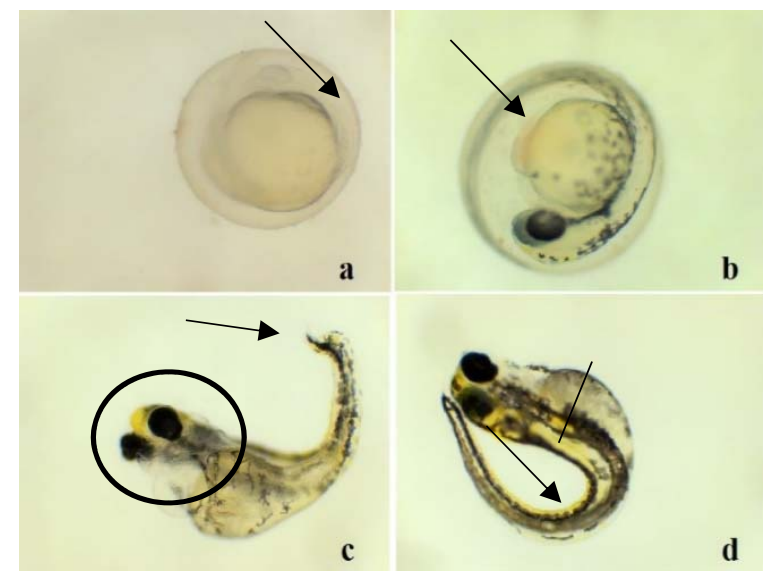

Şekil 11. $0.453 \mathrm{mg} \mathrm{L}^{-1}$ tribenuron metil uygulaması yapılmış embriyo ve larvaları a) 1. gün zebra balığı prelarvası gelişim geriliği, vitellüs kesesinde ödem (ok) b) 3. gün zebra balığı prelarvası perikardiyal ödem ve içerisinde kanlanma (ok), c) 5. gün zebra balığı embriyosunda koryondan çıkan balığın kuyruğunda eğrilik (ok), perikardiyal ödem (çember), vitellüs kesesinde ödem (çizgi), d) 5. gün zebra balığı embriyosunda omurgada eğrilik (ok)
3.1.6. $0.906 \mathrm{mg}^{-1}$ Tribenuron metil uygulaması yapılmış grup

Deney grubu dört kere tekrarlanmak üzere; $0.906 \mathrm{mg} \mathrm{L}^{-1}$ tribenuron metil uygulaması yapılmış zebra balığı embriyoları kontrol grupları ile karşılaştırıldığında toplam 80 embriyo içerisinde 36's1 1. gün öldü. Kalan 44 embriyoda anomali gözlendi. Gelişimin 1. gününde vitellüs kesesinde ödem (Şekil 12a), 3. gününde koryondan çıkan bazı embriyolarda vitellüs kesesinde ödem, perikardiyal ödemle ve omurga ile kuyruğunda eğrilik görüldü (Şekil 12b). 4. gününde bazı embriyolar koryondan çıkış, perikardiyal ödem, vitellüs kesesinde ödem ve kuyrukta eğrilik gözlendi (Şekil 12c). Ayrıca 5. gününde koryondan çıkışını henüz yapmış bazı balıkların omurgasında eğrilik, gelişim bozukluğu, vitellüs kesesinde ve perikardiyal kısmında ödem gözlendi (Şekil 12d). Bazı embriyoda ise omurgada hasar sonucu kanlanma izlendi (Şekil 13). Bu anomalilere ilaveten ilk 3 günde kalp atışı ortalama dakikada $73 \mathrm{kez}$ olarak hesaplandı. 


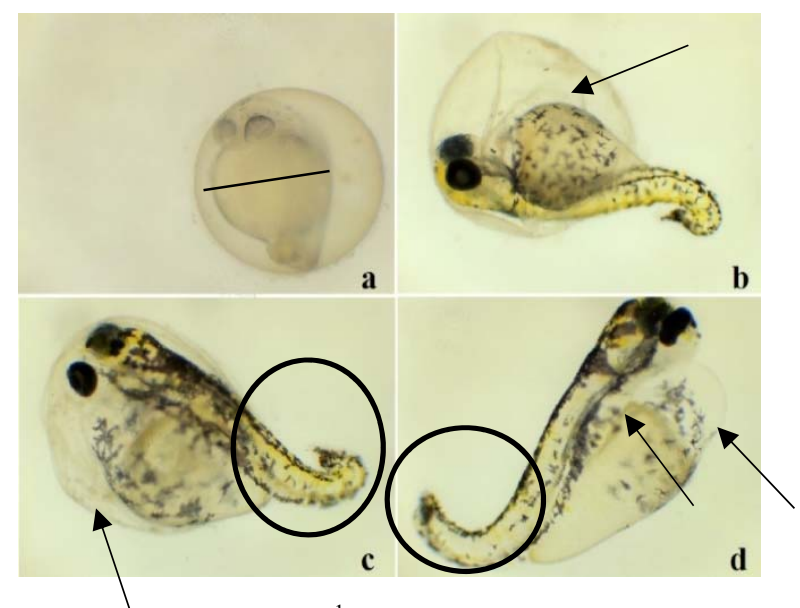

Şekil 12. $0.906 \mathrm{mg} \mathrm{L}^{-1}$ Tribenuron metil uygulaması yapılmış embriyo ve larvaları a) 1.gün zebra balığı prelarvası vitellüs kesesinde ödem (çizgi) b) 3. gün zebra balığı prelarvası perikardiyal ve vitellüs kesesi ödem (ok), omurga ile kuyrukta eğrilik c) 4. gün zebra balığı embriyosunda koryondan çıkan balığın kuyruğunda ve omurgasında eğrilik (daire), perikardiyal ödem, vitellüs kesesinde ödem (ok), d) 5 . gün koryondan henüz çıkmış zebra balığı embriyosunda omurgada eğrilik (daire), gelişim geriliği, perikardiyal ve vitellüs kesesinde ödem (ok).

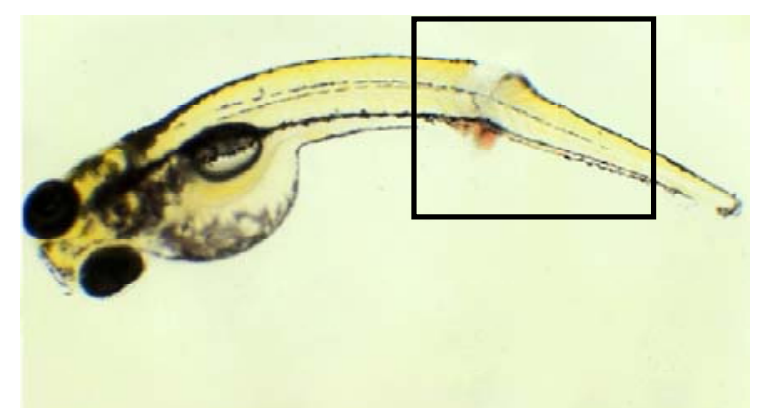

Şekil 13. $0.906 \mathrm{mg} \mathrm{L}^{-1}$ Tribenuron metil uygulaması yapılmış 5. gün koryondan çıkmış embriyonun omurgasında hasar ile kan birikimi (kare)

\subsection{7. $1.812 \mathrm{mg}^{-1} \quad \mathrm{~L}^{-1}$ Tribenuron} metil uygulaması yapılmış grup

Deney grubu dört kere tekrarlanmak üzere; $1.812 \mathrm{mg} \mathrm{L}^{-1}$ tribenuron metil uygulaması yapılmış zebra balığ embriyolar1 kontrol grupları ile karşılaştırıldığında toplam 80 embriyo içerisinde 63'ü 1. gün öldü. Kalan 17 embriyodan 17 'si ise 2 gün yaşayabildi ve bu iki günde anomali gözlendi. Gelişimin 1. gününde vitellüs kesesinde ödem (Şekil 14a), 2. gününde yaşayan embriyolarda vitellüs kesesinde ödem, gelişim geriliği ve omurga ile kuyruğunda eğrilik görüldü (Şekil 14b). 2. gününde yaşayan başka embriyoda ise göz ve belirgin kafa oluşumu olmadığ1, vitellüs kesesinde ödem ve omurga ile kuyrukta eğrilik olduğu gözlendi (Şekil 14c). Yine 2. gününde yaşayan başka bir embriyoda omurgasında eğrilik, gelişim geriliği ve vitellüs kesesinde ödem gözlendi (Şekil 14d). Bu anomalilere ilaveten ilk 2 günde kalp atışı ortalama dakikada $63 \mathrm{kez}$ olarak hesapland1.

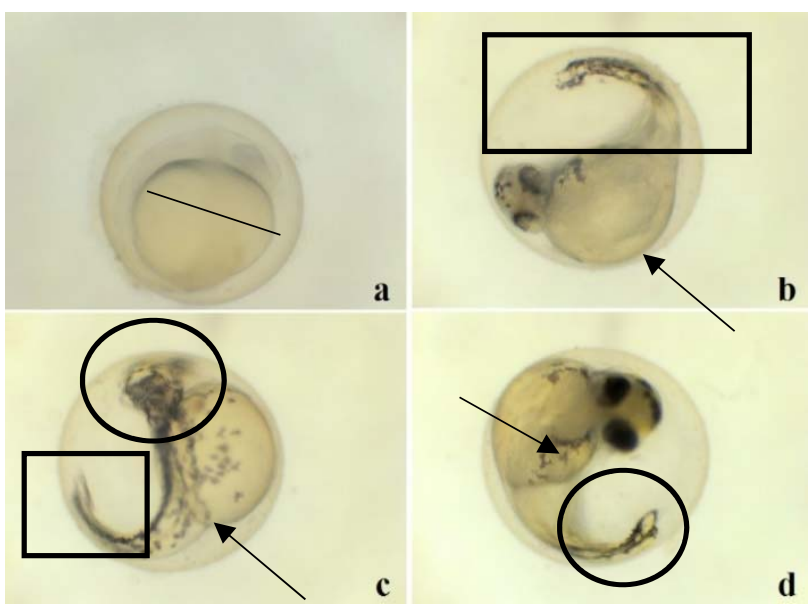

Şekil 14. $1.812 \mathrm{mg} \mathrm{L}^{-1}$ Tribenuron metil uygulaması yapılmış embriyo ve larvaları a) 1. gün zebra balığı prelarvası vitellüs kesesinde ödem (çizgi) b) 2. gün zebra balığı vitellüs kesesi ödem (ok), omurga ile kuyrukta eğrilik (kare) c) 2. gün zebra balığ1 embriyosunun kuyruğunda ve omurgasında eğrilik (kare), vitellüs kesesinde ödem (ok), belirgin göz ve baş yapısının oluşmaması (daire) d) 2. gün zebra balığı embriyosunda omurgada ve kuyrukta eğrilik (daire), vitellüs kesesinde ödem (ok)

\section{2. İstatistiksel Bulgular}

IBM SPSS 23 programı ile kontrol grupları ve uygulama doz grupları normallik testleri sonucu uygun ANOVA testi kullanıldı. ANOVA testi istatistiksel olarak anlamlı farklar çıktığı için, Doz grupları 
arasındaki farklar için TUKEY HSD testine

göre tribenuron metilin gelişimsel

anomalilere neden olduğu ispatland

$(\mathrm{p}<0.05)$.

Tablo 1. Tribenuron metilin zebra balığı embriyo ve larvalarına gelişimsel anomali oranı tablosu

\begin{tabular}{|c|c|c|c|c|c|}
\hline \multicolumn{6}{|c|}{ Tribenuron metilin ZB Anormali Tablosu (Ortalama \pm Std) } \\
\hline & 24 Saat & 48 Saat & 72 Saat & 96 Saat & 120 Saat \\
\hline $1.812 \mathrm{mg} \mathrm{L}^{-1}$ & $4.25 \pm 1.09^{*}$ & $0.00 \pm 0.00$ & $0.00 \pm 0.00$ & $0.00 \pm 0.00$ & $0.00 \pm 0.00$ \\
\hline $0.906 \mathrm{mg} \mathrm{L}^{-1}$ & $11.00 \pm 0.71^{*}$ & $9.50 \pm 0.50 *$ & $9.50 \pm 0.50 *$ & $9.50 \pm 0.50 *$ & $9.50 \pm 0.50 *$ \\
\hline $0.453 \mathrm{mg} \mathrm{L}^{-1}$ & $6.75 \pm 1.09^{*}$ & $6.00 \pm 0.71^{*}$ & $6.00 \pm 0.71^{*}$ & $6.00 \pm 0.71^{*}$ & $6.00 \pm 0.71 *$ \\
\hline $0.226 \mathrm{mg} \mathrm{L}^{-1}$ & $2.50 \pm 0.50^{*}$ & $2.50 \pm 0.50^{*}$ & $2.50 \pm 0.50 *$ & $2.50 \pm 0.50 *$ & $2.50 \pm 0.50 *$ \\
\hline $0.113 \mathrm{mg} \mathrm{L}^{-1}$ & $1.25 \pm 0.43$ & $1.25 \pm 0.43$ & $1.25 \pm 0.43$ & $1.25 \pm 0.43$ & $1.25 \pm 0.43$ \\
\hline $0.056 \mathrm{mg} \mathrm{L}^{-1}$ & $0.00 \pm 0.00$ & $0.00 \pm 0.00$ & $0.00 \pm 0.00$ & $0.00 \pm 0.00$ & $0.00 \pm 0.00$ \\
\hline Kontrol & $0.00 \pm 0.00$ & $0.00 \pm 0.00$ & $0.00 \pm 0.00$ & $0.00 \pm 0.00$ & $0.00 \pm 0.00$ \\
\hline
\end{tabular}

* Kontrol Grubundan p<0.05 düzeyinde istatiksel olarak anlamlı farklılık göstermiştir. TUKEY HSD testi.

Tribenuron metil uygulaması sonucu zebra sürelerinin de uzadığı sonucuna varıldı balığ embriyolarının koryondan çıkış oranı (Şekil 15). Aynı şekilde doz miktarı artışına (Şekil 15), ölüm oranı (Şekil 16) ve paralel olarak ölüm (Şekil 16) ve gelişimsel gelişimsel anomalilerin oranı (Şekil 17) anomali gösteren balıkların sayısının arttı̆̆ı TUKEY testi analiziyle değerlendirildi. görüldü (Şekil 17).

Uygulanan tribenuron metil miktarı arttıkça zebra balığı embriyolarının koryondan çıkış

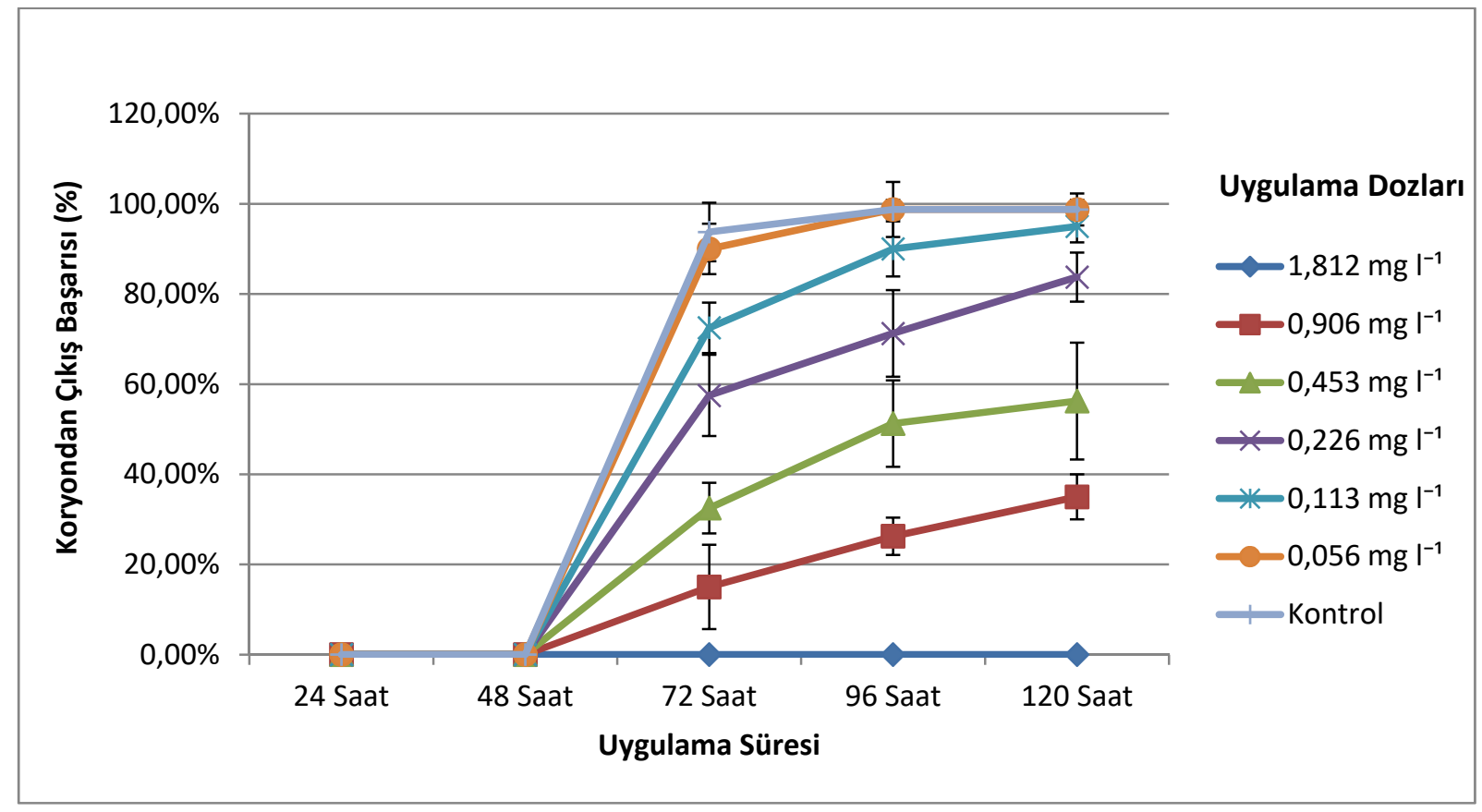

Şekil 15. Tribenuron metil uygulanmış zebra balığı embriyolarının koryondan çıkış oranları (\%). 


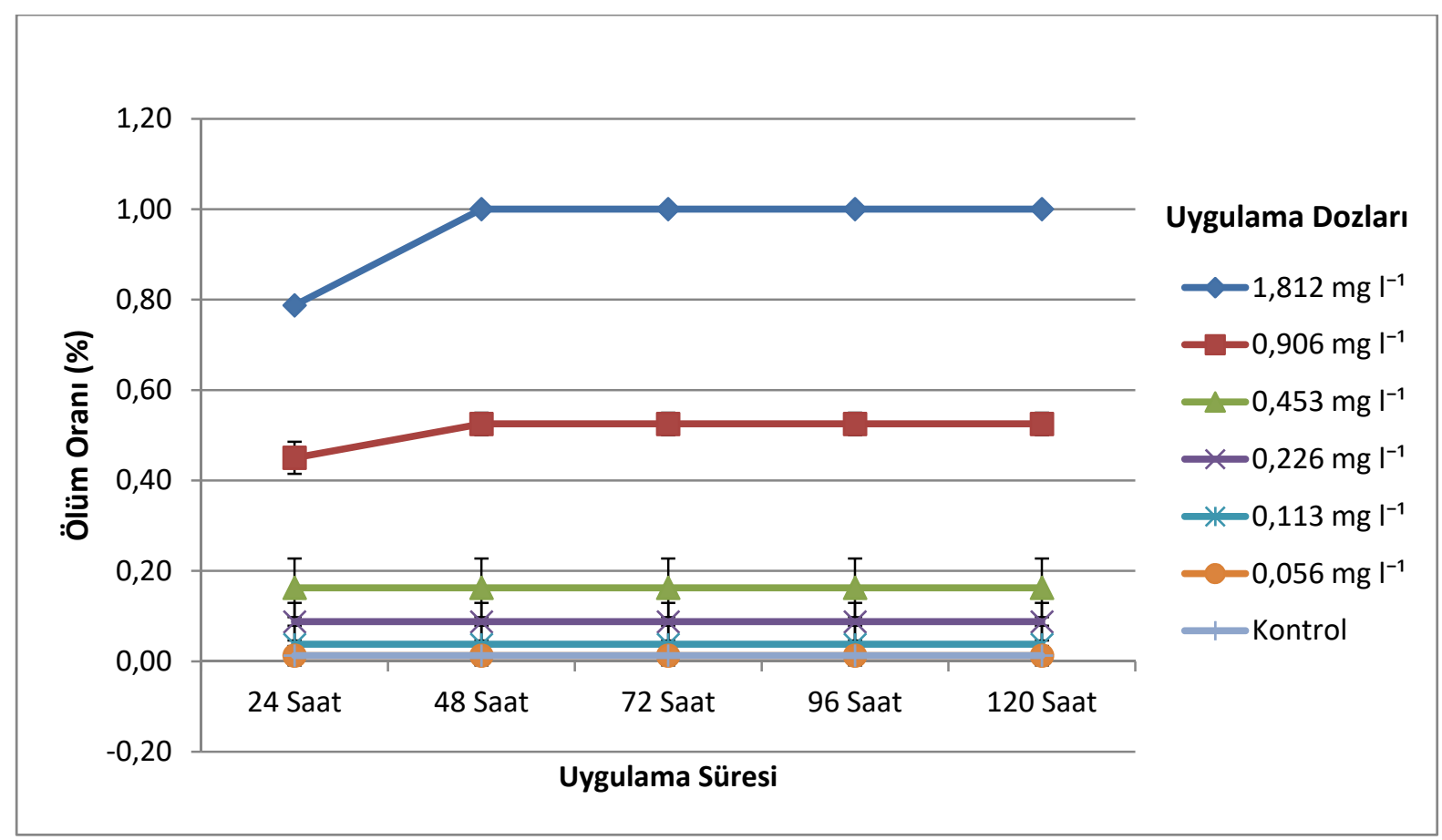

Şekil 16. Tribenuron metil uygulanmış zebra balığı embriyolarının ölüm oranı.

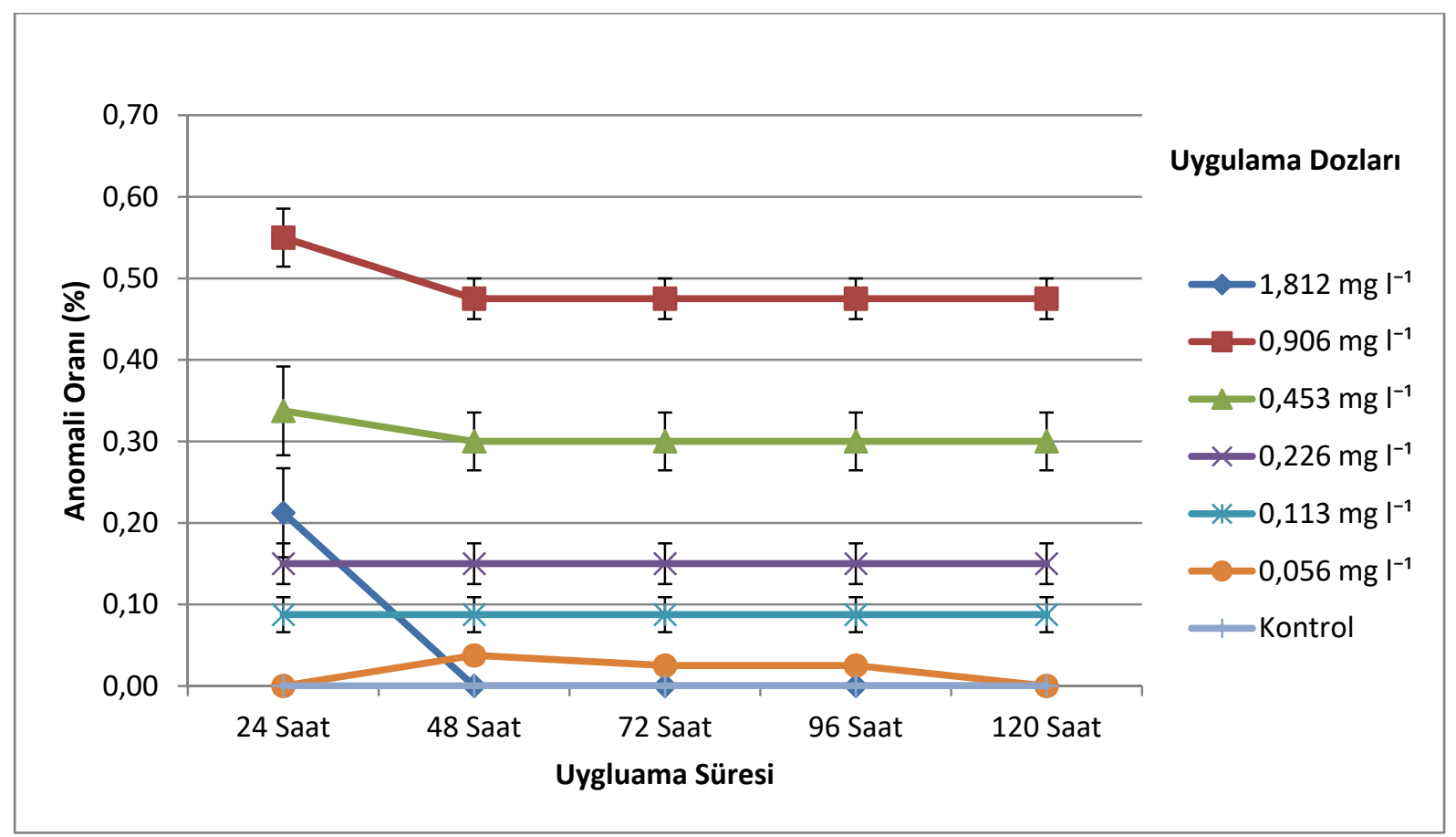

Şekil 17. Tribenuron metil uygulanmış zebra balığı embriyolarının gelişimsel anomali oranları (\%).

\section{Tartışma}

$\mathrm{Bu}$ çalışmada herbisit çeşitlerinden biri olan tribenuron metilin zebra balı̆̆ embriyo ve larvalarındaki etkileri teratolojik açıdan incelenmiştir. Laboratuvar koşullarında elde edilen embriyolara 6 farklı konsantrasyonda (1.812 $\mathrm{mg} \mathrm{L}^{-1}, 0.906 \mathrm{mg} \mathrm{L}^{-}$ 
1, $0.453 \mathrm{mg} \mathrm{L}^{-1}, 0.226 \mathrm{mg} \mathrm{L}^{-1}, 0.113 \mathrm{mg} \mathrm{L}^{-1}$, $0.056 \mathrm{mg} \quad \mathrm{L}^{-1}$ ) tribenuron metil uygulanmıştır. Tribenuron metilin embriyolar üzerinde meydana getirdiği teratolojik hasarlar 120 saat boyunca gözlenmiş ve bu sonuçlar istatistiksel olarak yorumlanmıştır. İnceleme sonucunda doz miktarı arttıkça koryondan çıkış sürelerinde gecikme, omurga ve kuyrukta eğrilik, perikardiyal ve vitellüs kesesinde ödem ile kalp atış hızında azalma gözlendi.

Akbulut ve ark. (2017) tarafindan yapılan çalışmada LC50'ye göre (40, 80 ve $120 \mathrm{mg} \mathrm{L}^{-1}$ ) tribenuron metil, zebra balığ dişilerine uygulanmış ve balıkların ovaryum yapısında meydana gelen değişimler 72 . saatin sonunda histolojik yöntemlerle incelenmiştir. Doz miktarı arttıkça ovaryum yapısında vakuolizasyon, ödem ve morfolojik bozulmalar gözlenmiştir. Ayrıca bu çalışma sonucunda primer ve olgun oosit sayısında doz arttıkça azalmalar olduğu istatistiksel olarak saptanmıştır. Bizim çalışmamızda ise embriyo üzerine yapılan incelemede; bu çalışmada olduğu gibi belirlenen LC50'ye göre doz arttıkça anomalilerin olduğu belirlenmiştir.

Pestisit çeşitlerinden herbisitlerin sucul canlılar üzerinde ölümcül etkiye sahip olduğu çalışmalarda incelenen konudur (Perez ve ark., 2011). Tribenuron metil; sucul canlılarda az çalışılmıştır. Yön ve ark. (2016) tribenuron metilin zebra balığının dalak dokusundaki hücrelerinde vakuolizasyon, hiperplazi ve yumuşak dokunda parçalanma meydana getirdiğini tespit etmişler ve 40,80 ve $120 \mathrm{mg} \mathrm{L}^{-1}$ 'lik doz miktarları arttıkça dalak dokularında anomali durumunun arttığını bildirmişlerdir.

Baghfalaki ve ark. (2012) ise gümüş sazanı (Hypophthalmicthys molitrix), aynalı sazan (Cyprinus carpio) ve kardan balığ 1 (Rutilus rutilus caspicus)'a 0, 50, 100, 200, 300 ve 500 ppm dozlarında tribenuron metil uygulamışlardır. Doz miktarı arttıkça balıkların davranışsal tepkilerinin (hızlı solungaç hareketi, yüzeyde yüzme hareketi, vücutta pigment azalması ve mukus salgısının artması) arttığını belirtmiştir. $\mathrm{Bu}$ çalışma sonucunda Avrupa Birliği Sınıflandırmasına göre tribenuron metil N R 50/53 ECB olduğunu göstermişlerdir. Yani tribenuron metil suda yaşayan canlılar için çok toksik olup uzun vadede olumsuz etkilere neden olabileceği belirtilmiştir. Bizim çalışmamızın sonucuna göre ise maddenin zebra balığı embriyolarına zarar verdiği tespit edilmiştir.

Tribenuron metil tarımda herbisit olarak yaygın kullanılmasına rağmen balıklar ve diğer sucul canlılara etkisi hakkında az bilgi vardır. Chen ve ark. (2018), suni toprak içerisinde yaşayan Toprak solucanı (Eisenia fetida) üzerine uygulanan tribenuron metil'in etkisini incelemişlerdir. Çalışmada maddenin solucanda selüloz aktivite azalması ve bununla birlikte toprağın yapısını olumsuz 
yönde etkilediğini sonuçlandırmışlardır. Maddenin tahriş etme ve yok etme yapısından dolayı zarar verdiği düşünülmüştür. Rachedi ve ark. (2018) ise tribenuron metili, toprakta yaşayan ve ekolojik döngüyü sağlayan aktinobakterilere (Actinobacteria) uygulayarak büyüme ve karakteristik direnç durumlarını incelemişlerdir. Çalışma sonucunda maddenin aktinobakterilerde (Actinobacteria) morfolojik hasar oluşturduğu ve canlının maddeye karşı adaptasyon göstermediği ve direnç oluşturmadığını belirtmişlerdir. Marzouk ve ark. (2012), tribenuron metilin sıçanda (Rattus) kemik iliği hücrelerindeki sitogenetik etkilerini incelemişler ve maddenin zararlı olduğunu tespit etmişlerdir. Bu çalışmaya göre dozlar 5, 25, 50 ve $100 \mathrm{mg}$ ve 48 saat aralıkla 21 gün boyunca uygulanmıştır. Çalışma sonucunda doz miktarı arttıkça mitotik aktivitede azalma ile kromozomal anomaliliklerin sıklığında artış göstermişlerdir.

Herbisit çeşitlerinin, balık gelişimine teratolojik etki vermesi çalışmalarda incelenen konudur. Wiegand ve ark. (2001), Atrazine'nin (2-chloro-4-ethylamino-6isopropylamine-s-triazine) zebra balı̆ 1 (Danio rerio) gelişimi üzerindeki teratolojik etkilerini incelemişlerdir. Çalışmada 4, 10 ve $20 \mathrm{mg} \mathrm{L}^{-1}$ doz solüsyonları içerisindeki embriyoların gelişimi 48 saat boyunca izlenmiştir. Çalışma sonucunda doz arttıkça koryon çıkışında gecikme, epiboli süresinde gecikme ve kalp, dolaşım gibi fonksiyonel bozukları tespit etmişlerdir. Maddenin balık gelişimine morfolojik hasarlar biraktığ düşünülmüştür. Bizim çalışmamızda da benzer bulgular elde edilmiştir.

Perez ve ark. (2013), s-trazin (atrazin ve terbutilazin) herbisitin zebra balığ (Danio rerio) gelişimi üzerindeki etkilerini incelemişlerdir. Çalışmada ikili herbisit karışımından oluşan solüsyonun, embriyoda sinerjistik etki ve morfolojik bozulmalara neden olduğu; ayrıca larvada yüzme davranışlarında bozulma olduğunu tespit etmişlerdir. Çalışmamızda ise kullanılan herbisitin dozu arttıkça, zebra balığ larvasında vitellüs kesesinde ödem ve omurgada var olan eğriliğinden dolayı dengeli yüzemediği gözlenmiştir. Velki ve ark. (2017) Diuron adlı herbisitin zebra balığı (D. rerio) embriyo ve larvalarının akut toksisitesi ve davranışlarına etkilerini incelemişlerdir. 1.2 ve $3.8 \mathrm{mg} \mathrm{L}^{-1}$ Diuron uygulamaları sonucu embriyolarda davranışsal değişikler, koryon içerisinde kendiliğinden kıvrılma hareketlerinde azalma ve doz arttıkça kalp atışında azalma tespit etmişlerdir. Çalışmamızda ise kullandığımız tribenuron metilin dozu arttıkça kalp atışında azalma olduğu görülmüştür.

Bir herbisit türü olan metamifob zebra balığı embriyolarında anormalliklere neden olmuş, embriyolarda oksidatif stres ve 
hücre apoptozunu indüklemiştir (Zhao, 2019). Farklı dozda benoxacor uygulaması sonucu zebra balığı embriyolarında çok sayıda malformasyon gözlenirken, en belirgin malformasyon vücut eğriliği olduğu açıklanmıştır. Bunun yanında kalp atış sayısında azalma olduğu belirtilmiştir (Liu ve ark., 2020). Chen ve ark. (2020) tarafından yapılan çalışmada tralopiril uygulanmas1 sonucu zebra balığ1 embriyolarında gelişimsel toksisite gözlenmiştir. Tralopiril'in zebra balığ embriyolarında tiroit hormon konsantrasyonunu düşürdügü, amino asit ve lipit metabolizmasını etkilediği açıklanmıştır. Embriyonik gelişimdeki bozukluğun metabolizma ve tiroit sistemi bozukluğundan kaynaklanabileceği açıklanmıştır. 2,4-D uygulaması zebra balığı embriyolarında, boyda kısalma, perikardiyal ödem ve vitellüs kesesi malformasyonlarına neden olmuştur (Li ve ark., 2017).
Sonuç olarak, farklı herbisitlerin canlıların embriyo, davranış ve dokuları üzerine olumsuz etkileri çeşitli çalışmalarla ortaya çıkarılmıştır. Yapılan literatür taramas1 sonucunda herhangi bir model organizmada tribenuron metilin embriyo üzerine etkilerini gösteren bir çalışmaya rastlanamamıştır. $\mathrm{Bu}$ bağlamda çalışmamız öncü bir çalışmadır. Farklı dozlarda olsa bile herbisitlerin ekosisteme girmesi pek çok canlıya zarar vermektedir. $\mathrm{Bu}$ bağlamda tribenuron metil ve bunun gibi herbisitlerin maruziyetinden mümkün olduğunca kaçınılmalıdır. Tribenuron metil uygulamasının dokuların hücre morfolojisinde değişimlere sebep olduğu histolojik çalışmalar ile gösterilmiştir. $\mathrm{Bu}$ çalışmanın bu konuda yapılacak diğer çalışmalara temel olacağı düşünülmektedir.

\section{Kaynaklar}

Akbulut C, Ozturk B, Uzun A, Yon ND (2017). Tribenuron methyl exposure inhibits oogenesis in zebrafish (Danio rerio). Indian J Fish 64: 127-131.

Baghfalaki M, Shaluei F, Hedayati A, Jahanbakhshi A, Khalili M (2012). Acute toxicity assessment of tribenuron-methyl herbicide in silver carp (Hypophthalmicthys molitrix), common carp (Cyprinus carpio) and Caspian roach (Rutilus rutilus caspicus). Global Veterinaria 8: 280-284.

Chen J, Saleem M, Wang C, Liang W, Zhang Q (2018). Individual and combined effects of herbicide tribenuron-methyl and fungicide tebuconazole on soil earthworm (Eisenia fetida). Scientific Reports 8: 1-9.

Chen X, Teng M, Zhang J, Qian L, Duan M, Cheng Y, Zhao F, Zheng J, Wang C (2020). Tralopyril induces developmental toxicity in zebrafish embryo (Danio rerio) by disrupting the thyroid system and metabolism. Science of the Total Environment 746: 141860 . 
EPA (Environmental Protection Agency) (2009). Types of Pesticides. Washington D.C., USA.

Glaberman S, Padilla S, Baron MG (2017). Evaluating the zebrafish embryotoxicity test for pesticide hazard screening. Environmental Toxicology and Chemistry 36: 1221-1226.

Glaberman S, Padilla S, Barron MG (2017). Evaluating the zebrafish embryo toxicity test for pesticide hazard screening. Environ Toxicol Chem 36: 1221-1226.

IBM Corp (2015). IBM SPSS Statistics for Windows, Version 23.0. Armonk, NY: IBM Corp.

Kimmel CB, Ballard WW, Kimmel SR, Ullman B, Schilling TF (1995). Stages of embryonic development of zebrafish. Developmental Dynamics 203: 253-310.

Li K, Wu J, Jiang L, Shen L, He Z, Wei P, Lv Z, He MF (2017). Developmental toxicity of 2, 4-dichlorophenoxyacetic acid in zebrafish embryos. Chemosphere 171: 40-48.

Liu S, Deng X, Bai L (2020). Developmental toxicity and transcriptome analysis of zebrafish (Danio rerio) embryos following exposure to chiral herbicide safener benoxacor. Science of the Total Environment 143273.

Marzouk A, Mossa H, Sabra F (2012). Cytogenetic effects of technical and formulated Tribenuron-methyl on rat bone-marrow cells. Journal of Pharmacology and Toxicology 7: 330-337.

Perez GL, Vera MS, Miranda LA (2011). Effects of herbicide glyphosate and glyphosatebased formulations on aquatic ecosystems. Herbicides and Environment 16: 343-368.

Pérez J, Domingues I, Monteiro M, Soares AM, Loureiro S (2013). Synergistic effects caused by atrazine and terbuthylazine on chlorpyrifos toxicity to early-life stages of the zebrafish (Danio rerio). Environmental Science and Pollution Research 20: 4671-4680.

Rachedi K, Zermane F, Tir R, Ayache F, Duran R, Lauga B, Boulahrouf A (2018). Effect of sulfonylurea tribenuron methyl herbicide on soil actinobacteria growth and characterization of resistant strains. Brazilian Journal of Microbiology 49: 79-86.

Toros S, Maden S (1985). Tarımsal Savaş Yöntem ve İlaçları. A.Ü. Ziraat Fakültesi Yayınları, Ankara.

Tyler SA, Gurian J (1950). Determination of the LD50 by use of probit, angular, and logit transformations. United States. https://doi.org/10.2172/4420363

Velki M, Paolo C, Nelles J, Seiler T, Hollert H (2017). Diuron and diazinon alter the behavior of zebrafish embryos and larvae in the absence of acute toxicity. Chemosphere 180: 6576.

Vural N (1984). Toksikoloji. A.Ü. Basımevi, Ankara.

Wiegand C, Krause E, Steinberg C, Pflugmacher S (2001). Toxicokinetics of atrazine in embryos of the zebrafish (Danio rerio). Ecotoxicology and Environmental Safety 49: 199-205.

Yön ND, Öztürk B, Akbulut C (2016). Histological effects of tribenuron methyl spleen tissue of zebrafish. $2^{\text {nd }}$ International Congress of Forensic Toxicology Industrial and Environmental Toxicology, Ankara-Turkey.

Zhao F, Li H, Cao F, Chen X, Liang Y, Qui L (2019). Short-term developmental toxicity and potential mechanisms of the herbicide metamifop to zebrafish (Danio rerio) embryos. Chemosphere 236: 124590. 